\title{
Pelaksanaan Tugas Polri Mendukung Penerapan Protokol Kesehatan Di Masa Pandemi Covid-19
}

\section{The Implementation Of Police's Tasks Supporting The Implementation Of Health Protocols During The Covid- 19 Pandemic}

\author{
Iswidodo ${ }^{1}$ \\ Kepolisian Republik Indonesia Polres Bima \\ Taufik Firmanto ${ }^{2}$ \\ Prodi Ilmu Hukum: STIH Muhammadiyah Bima \\ (taufik.f12@gmail.com) \\ Muhammad Amin ${ }^{3}$ \\ Prodi Ilmu Hukum: STIH Muhammadiyah Bima
}

Abstrak: Tulisan ini bertujuan untuk meninjau dan menganalisis pelaksanaan tugas Polri guna mendukung penerapan protokol kesehatan selama pandemi Covid-19 dalam rangka terwujudya situasi kamtibmas yang kondusif. Metode yang digunakan dalam penelitian dan penulisan ini adalah metode penelitian hukum normatif, dengan beberapa pendekatan yang biasa digunakan dalam penelitian hukum, antara lain; pendekatan perundang-undangan, pendekatan konsep, pendekatan kasus, pendekatan analisis, dan pendekatan historis. Hasil temuan menunjukkan bahwa sesuai fungsinya, Polri telah melaksanakan tugas guna mendukung penerapan protokol kesehatan selama pandemi Covid-19 dalam rangka terwujudya situasi kamtibmas yang kondusif. Hal tersebut dilaksanakan dengan cara antara lain: Pertama, preventif: menerbitkan STR untuk panduan anggota melaksanakan Tindakan-tindakan pada masa pandemi dan masa transisi Normal Baru, Binmas, Sabhara, Lalu Lintas dan satker-satker lainnya terlibat aktif memberikan informasi dan penyadaran pada masyarakat. Bersama-sama dengan Pemerintah Daerah menjaga keamanan dan ketertiban masyarakat dengan memanfaatkan teknologi, misalnya dengan CCTV, drone, aplikasi-aplikasi online. 
Merangkul masyarakat dengan humanis, sehingga masyarakat yang terdampak Covid-19 secara kesehatan maupun secara ekonomi dapat survive. Kedua: preemtif: melakukan patrolpatroli dan razia-razia untuk mencegah kejahatan. Ketiga: penegakan hukum sebagai upaya terakhir bagi orang-orang yang melakukan perlawanan meski melanggar, termasuk memerintahkan pengendara motor dan mobil untuk putar balik karena larangan mudik Lebaran.

Kata Kunci: covid-19; pandemi; polri; protokol kesehatan;

Abstract: This paper aims to review and analyze the implementation of Polri's duties to support the implementation of health protocols during the Covid-19 pandemic in order to realize a conducive security and social order situation. The method used in this research and writing is a normative legal research method, with several approaches commonly used in legal research, including; legislation approach, concept approach, case approach, analytical approach, and historical approach. The findings show that according to its function, the Police have carried out their duties to support the implementation of health protocols during the Covid-19 pandemic in order to create a conducive security and social order situation. This is carried out in the following ways: First, preventive: issuing STR to guide members in carrying out actions during the pandemic and the New Normal transition period, Binmas, Sabhara, Traffic and other satkers are actively involved in providing information and raising awareness to the public. Together with the Regional Government to maintain security and public order by utilizing technology, for example with CCTV, drones, online applications. Embracing the community with humanity, so that people affected by Covid-19 both healthily and economically can survive. Second: preemptive: conducting patrols and raids to prevent crime. Third: law enforcement as a last resort for people who resist even though they violate it, including ordering motorbikes and car drivers to turn back because of the ban on going home for Eid.

Keywords: covid-19; pandemic; police; health protocols; 


\section{PENDAHULUAN}

Kepolisian Republik Indonesia (Polri) adalah aktor utama pemeliharaan keamanan dalam negeri melalui upaya penyelenggaraan fungsi kepolisian yang meliputi pemeliharaan keamanan dan ketertiban masyarakat, penegakan hukum, perlindungan, pengayoman, dan pelayanan kepada masyarakat yang dilakukan oleh Kepolisian Negara Republik Indonesia selaku alat negara yang dibantu oleh masyarakat dengan menjunjung tinggi hak asasi manusia (HAM). Tak kurang, Pada peringatani Hari Ulang Tahun Bhayangkara ke-74, Rabu, 1 Juli 2020, kiprah Polri dalam melindungi rakyatnya, semakin diakui terutama dalam membantu penanganan Covid19. Di masa pandemi saat ini, Polri telah berjasa memelihara keamanan dan ketertiban masyarakat. Sesuai asas Salus Populi Suprema Lex Esto (keselamatan rakyat merupakan hukum tertinggi) yang senantiasa menjadi prinsip Polri dalam menjalankan tugasnya.

Di tengah pandemi Covid-19 ini, tugas Polri semakin kompleks tidak hanya mengatasi masalah kejahatan, radikalise, terorisme, dan narkotika, namun juga bertambah termasuk pada upaya untuk melawan Covid 19 (coronavirus disease 2019). Covid-19 adalah penyakit yang disebabkan oleh jenis coronavirus baru yaitu SarsCoV-2, yang dilaporkan pertama kali di Wuhan Tiongkok pada tanggal 31 Desember 2019. Covid-19 ini dapat menimbulkan gejala gangguan pernafasan akut seperti demam diatas $38^{\circ} \mathrm{C}$, batuk dan sesak nafas bagi manusia. Selain itu dapat disertai dengan lemas, nyeri otot, dan diare. Pada penderita Covid-19 yang berat, dapat menimbulkan pneumonia, sindroma pernafasan akut, gagal ginjal bahkan sampai kematian. Covid-19 dapat menular dari manusia ke manusia melalui kontak erat dan droplet (percikan cairan pada saat bersin dan batuk), tidak melalui udara. Bentuk Covid-19 jika dilihat melalui mikroskop elektron (cairan saluran nafas/ swab

1. Alam, K., \& Kusumah, A. D. (2021). Optimalisasi Strategi Polmas Guna Mendukung Penerapan Protokol Kesehatan Selama Pandemi Covid-19 Dalam Rangka Terwujudnya Situasi Kamtibmas Yang Kondusif. Yustitia, 7(1), 40-56. 
tenggorokan) dan digambarkan kembali bentuk Covid-19 seperti virus yang memiliki mahkota. ${ }^{2}$

Untuk pencegahan dan penanganan Covid-19 di Indonesia, pemerintah membentuk Gugus Tugas Percepatan Penanganan, di mana Polri ikut menjadi bagian. Membahas peran Polri, hal tersebut tidak akan terlepas dari fungsi, tujuan, peran, dan tugas pokok Polri sebagaimana yang diamanatkan pada Undang-undang Nomor 2 Tahun 2002 tentang Kepolisian Negara Republik Indonesia.

Penularan virus SARS-CoV-2 masih terjadi di tengah masyarakat. Penyebaran Covid-19 yang berkelanjutan dapat memicu dan memperburuk berbagai permasalahan sosial-ekonomi. Kepatuhan dan kedisplinan dalam penerapan protokol kesehatan menjadi salah kunci penanganan Covid-19. Upaya pencegahan dan pemutusan rantai penyebaran Covid-19 di Indonesia membutuhkan kedisiplinan pada banyak aspek terutama kehidupan sosial masyarakat. Dalam situasi pandemi diperlukan disiplin yang sangat ketat terhadap kehidupan sosial masyarakat dalam bentuk physical distancing. Metode ini dianggap sebagai upaya yang paling efektif untuk mencegah dan mengurangi angka penyebaran virus ini. ${ }^{3}$

Sejalan dengan hal tersebut, guna mendukung penerapan Protokol Kesehatan, Polri melakukan langkah-langkah dalam upaya menghadapi pandemi Covid-19 di seluruh wilayah Indonesia. Polisi mulai menindak warga yang berkerumun hingga memberikan bantuan sembako kepada warga yang terdampak pandemi Covid-19. Karopenmas Divhumas Polri Brigjen Awi Setiyono mengatakan, sejak 19 Maret 2020 lalu, Polri telah melaksanakan Operasi Aman Nusa Il. Melalui Operasi Aman Nusa selama ini, Polri sudah melakukan segala upaya dalam memutus dan memerangi mata rantai Covid-19. Mulai dari pendisiplinan masyarakat melalui adaptasi kebiasaan baru untuk mematuhi protokol kesehatan terkait Covid-19. ${ }^{4}$

Hingga Januari 2021, Pemerintah melalui Satuan Tugas Penanganan Covid-19 melaporkan bahwa penularan virus corona masih terus bertambah Berdasarkan data yang disampaikan Satuan Tugas Penanganan Covid-19, Sabtu sore, ada penambahan 12.191

\footnotetext{
2.http: / / www.padk.kemkes.go.id/article/read/2020/04/23/21/hindari-lansiadari-covid-19.html diakses pada 23/01/2021

${ }^{3}$.https://kompolnas.go.id/tugas-polri-semakin-berat-di-masa-pandemi// diakses pada $23 / 01 / 2021$

${ }^{4}$.http://infopublik.id/kategori/lawan-covid-19/453015/upaya-polri-dalammenghadapi-pandemi-covid-19 diakses pada 27/01/2021
} 
kasus baru Covid-19 dalam sehari. Penambahan itu menyebabkan kasus Covid-19 di Tanah Air kini mencapai 977.474 orang, terhitung sejak diumumkannya kasus pertama pada 2 Maret 2020 (Satgas Covid, 2021).

Pandemi Covid-19 berdampak pada masyarakat tidak hanya di bidang kesehatan, melainkan juga di bidang ekonomi, keagamaan, sosial dan budaya, serta politik. Semua itu, tegasnya, jika tidak bisa dikelola dengan baik, maka akan berpotensi mengganggu situasi Kamtibmas. Di situlah peran Polri dibutuhkan agar potensi gangguan Kamtibmas tidak berkembang menjadi gangguan nyata. Seluruh anggota Polri harus bekerja ekstra keras dengan mengedepankan tindakan preemtif dan preventif.

Dalam rangka terwujudya situasi kamtibmas yang kondusif, pada masa Pandemi Covid 19 ini tugas Polri semakin kompleks dan banyak variannya. Kini Polri bukan lagi hanya menangani kriminalitas, kejahatan jalanan, kejahatan kerah putih, radikalisme sampai masalah narkoba, tetapi juga sebagai anggota Gugus Tugas Nasional Percepatan Penanganan Covid-19 Polri memiliki sejumlah tugas tambahan. Sebagai langkah preemtif Polisi bertugas memetakan wilayah yang rawan penyebaran virus corona. Dari uraian latar belakang, diajukan rumusan masalah bagaimana pelaksanaan tugas Polri guna mendukung penerapan protokol kesehatan selama pandemi Covid-19 dalam rangka terwujudya situasi kamtibmas yang kondusif.

\section{METODE}

Dalam penelitian ini, spesifik penelitian menggunakan penelitian yuridis normatif, yaitu penelitian yang difokuskan untuk mengkaji penerapan kaidah-kaidah atau norma-norma dalam hukum positif. $^{5}$ Dengan pendekatan pertama peraturan-perundangundangan pendekatan ini diperlukan memahami hierarki dan asasasas dalam peraturan perundang-undangan. ${ }^{6}$ Kedua Pendekatan Konseptual, pendekatan ini dilakukan dengan mengkaji konsepkonsep, teori-teori dan pendapat para ahli yang ada kaitanya

5 . Ibrahim, Johnny. "Teori dan metodologi penelitian hukum normatif." Malang: Bayumedia Publishing, (2006). hlm 295

6. Marzuki, Mahmud. Penelitian Hukum: Edisi Revisi. Prenada Media, 2017. hlm 137 
dengan objek yang diteliti dan pandangan atau doktrin yang berkembang dalam ilmu hukum dapat menjadi pijakan untuk menbangun argumentasi hukum ketika menyelesaikan isu hukum yang dihadapi. ${ }^{7}$

\section{HASIL DAN PEMBAHASAN}

\section{Temuan Di Lapangan Terkait Dengan Tupok Kepolisian pada} Masa Pandemi Covid-19

Virus Covid-19 adalah penyakit menular yang disebabkan oleh virus corona yang pertama kali ditemukan di Wuhan, China. Penyebaran Covid-19 dengan jumlah kasus dan/atau jumlah kematian telah meningkat dan meluas lintas wilayah dan lintas negara dan berdampak pada aspek politik, ekonomi, sosial, budaya, pertahanan dan keamanan, serta kesejahteraan masyarakat di Indonesia (PP 21/2020). Sebagian besar orang yang tertular Covid-19 akan mengalami gejala ringan hingga sedang, dan akan pulih tanpa penanganan khusus. Cara penyebaran Virus ini terutama ditransmisikan melalui droplet (percikan air liur) yang dihasilkan saat orang yang terinfeksi batuk, bersin, atau mengembuskan nafas. Droplet ini terlalu berat dan tidak bisa bertahan di udara, sehingga dengan cepat jatuh dan menempel pada lantai atau permukaan lainnya.

Masing-masing orang memiliki respons yang berbeda terhadap Covid-19. Sebagian besar orang yang terpapar virus ini akan mengalami gejala ringan hingga sedang, dan akan pulih tanpa perlu dirawat di rumah sakit. Gejala yang paling umum: demam, batuk kering, kelelahan. Sementara gejala yang sedikit tidak umum, yaitu rasa tidak nyaman dan nyeri, nyeri tenggorokan, diare, konjungtivitis (mata merah), sakit kepala, hilangnya indera perasa atau penciuman, ruam pada kulit, atau perubahan warna pada jari tangan atau jari kaki.

Covid-19 telah dinyatakan oleh WHO sebagai kedaruratan kesehatan masyarakat yang wajib dilakukan upaya penanggulangan. $^{8}$ Salah satunya berupa kebijakan physical

\footnotetext{
7.Irwansyah, Penelitian Hukum Pilihan Metode \& Praktik Penulisan Artikel, Yogyakarta, Mirra Buana Media, (2021), Hlm 133-152

${ }^{8}$.Telaumbanua, D. (2020). Urgensi Pembentukan Aturan Terkait Pencegahan Covid-19 di Indonesia. QALAMUNA: Jurnal Pendidikan, Sosial, Dan Agama, 12(01), 59-70. 1.290
} 
distancing. Meski pemerintah sudah memberlakukan physical distancing, masih banyak masyarakat yang melanggar. Pemerintah memperkuat kewajiban physical distancing melalui Peraturan Pemerintah Nomor 21 Tahun 2020 tentang Pembatasan Sosial Berskala Besar (PSBB) dan Peraturan Kementerian Kesehatan (Permenkes) No. 9 Tahun 2020. Aturan ini harus dipatuhi dan untuk memastikan kepatuhan tersebut, Polri menjadi garda terdepan.

Untuk menekan laju penularan Covid-19, pemerintah Indonesia mengimbau menjaga jarak fisik (physical distancing), kerja dari rumah, belajar di rumah, hingga beribadah di rumah. Berdasarkan imbauan tersebut sejumlah pemerintah daerah mengambil kebijakan dengan memberlakukan aturan belajar di rumah bagi siswa sekolah. Menurut Kepala Bidang Media dan Opini Publik Kementerian Busroni, social distancing dan karantina mandiri berperan besar dalam pencegahan dan penanganan untuk memperlambat penularan Covid-19 namun tidak ada maknanya jika menggunakan masa libur untuk berlibur ke luar, sama dengan memindahkan kontak dengan orang lain. Social distancing harus dipatuhi dan dilaksanakan dengan menahan diri di rumah, tidak melakukan kontak dengan orang lain.

Fungsi penegakan hukum dalam PSBB yang diemban Polri sesungguhnya tidak lepas dari fungsinya sebagaimana telah diatur dalam UU No. 2 Tahun 2002 Tentang Polri. Pasal 2 dalam UU ini menyebutkan bahwa salah satu fungsi kepolisian adalah fungsi pemerintahan negara di bidang pemeliharaan keamanan dan ketertiban masyarakat, penegakan hukum, perlindungan, pengayoman, dan pelayanan kepada masyarakat. Berdasarkan regulasi tersebut, maka istilah keamanan dalam konteks tugas dan fungsi Polri adalah "keamanan dan ketertiban masyarakat," di mana istilah ini mengandung dua pengertian:

a Pertama, sebagai suatu kondisi dinamis masyarakat, sebagai salah satu prasyarat terselenggaranya pembangunan nasional sebagai tujuan nasional yang ditandai oleh terjaminnya keamanan, ketertiban, tegaknya hukum, serta terbinanya ketentraman;

b Kedua, keamanan sebagai kemampuan membina serta mengembangkan potensi dan kekuatan masyarakat dalam menangkal, mencegah, dan menanggulangi segala bentuk 
pelanggaran hukum dan bentuk-bentuk gangguan lainnya yang dapat meresahkan masyarakat. ${ }^{9}$

Di masa pandemi Covid-19, peran Polri lebih ditekankan pada pengertian kedua karena pada masa PSBB, Polri mengemban fungsi penegakan hukum yang ditegaskan kembali melalui Maklumat Kapolri No. Mak/2/III/2020 tentang Kepatuhan Kebijakan Pemerintah dalam Penanganan Virus Corona. Maklumat tersebut merupakan inisiatif Polri dalam mendukung PP Nomor 21 Tahun 2020 tentang PSBB dan Permenkes No. 9 Tahun 2020.

Tugas tak kalah penting diperankan oleh Polri adalah keterlibatan dalam Program Vaksinasi Nasional. Pandemi Covid19 yang melanda Indonesia, selama itu pula TNI-POLRI dilibatkan dalam penanganannya. Baru-baru ini, puluhan ribu prajurit TNIPOLRI kembali dikerahkan sebagai tracer dan vaksinator dalam program vaksinasi nasional. Hal tersebut sesuai dengan arahan Presiden Joko Widodo yang menginstruksikan TNI-POLRI untuk bersinergi mendukung kebijakan pemerintah dalam program vaksinasi massal nasional. Pelibatan TNI-POLRI dalam program vaksin nasional didasari pada keterbatasan tenaga kesehatan yang dimiliki oleh Kementerian Kesehatan. Pandemi yang belum kunjung mereda ini menuntut respons yang cepat dan komprehensif dari pemerintah, termasuk melalui pengerahan TNI-POLRI dalam jumlah yang masif, namun tanpa mengesampingkan prinsip-prinsip yang dianut oleh Indonesia sebagai negara demokrasi. ${ }^{10}$

Pada tingkatan paling bawah yang bersentuhan langsung dengan masyarakat, Polri memiliki andil dalam penanggulangan pandemik Covid-19 tak dapat dinafikkan. Faktor internal yang dimiliki Polri dalam upaya optimalisasi personel Bhabinkamtibmas yang menjadi kekuatannya dalam pelaksanaan tugas Polri Guna Mendukung Penerapan Protokol Kesehatan Covid-19 diterapkan dengan adanya kebijakan terkait dasar dan pedoman juga Instruksi Presiden untuk pelaksanaan tugas Polri dalam mengatasi pandemik. Polda Jateng

9. Hermawan Sulistyo, et.al., Keamanan Negara, Keamanan Nasional, dan Civil Society: Policy Paper, Pensil-324, Jakarta, 2009

10. Aulia Fitri. TNI-Polri Dan Program Vaksinasi Nasional. Kajian Singkat Terhadap Isu Aktual Dan Strategis. Vol. XIII, No.4/II/Puslit/Februari/2021. Pusat Penelitian Badan Keahlian DPR RI, hlm. 25-30. 
menciptakan aplikasi E-MB yang dapat menunjang Polri dalam melaksanakan tugasnya. Penempatan personel dapat berjalan cepat dan lancar sehingga aparat Bhabin siaga pada pengamanan klaster Covid yang dituju. Meninjau faktor internal dan eksternal tersebut diperlukan strategi yang mampu mengoptimalkan pemberdayaan aparat Polri sebagai sumber daya pendukung dengan adanya upaya optimalisasi aplikasi EMutasi Bhabinkamtibmas dalam Penerapan Protokol Kesehatan Covid-19 di Polda Jateng. ${ }^{11}$

2. Fakta-Fakta Yang Masih Menjadi Kendala Dalam Pelaksanaan Tupok Kepolisian Selama Pandemi Covid-19

Update Corona Dunia 24 Januari 2021 telah mencapai angka 99 juta kasus, meskipun sejumlah negara telah memulai program vaksinasi, penyebaran virus corona secara global, masih terus bertambah dari hari ke harinya. Melansir data dari laman Worldometers, hingga Minggu (24/1/2021) pagi, total kasus Covid-19 di dunia terkonfirmasi sebanyak 99.278 .468 (99 juta) kasus. Dari jumlah tersebut, sebanyak 71.293 .958 (71 juta) pasien telah sembuh, dan 2.128.376 orang meninggal dunia. Kasus aktif hingga saat ini tercatat sebanyak 25.855.860 dengan rincian 25.744.955 pasien dengan kondisi ringan dan 111.179 dalam kondisi serius. ${ }^{12}$

Pemerintah melalui Satuan Tugas Penanganan Covid-19 melaporkan bahwa penularan virus corona masih terus bertambah, data perkembangan kasus Covid-19 di Indonesia, ada 162.617 pasien dirawat, ada $989.262+11.788$ Terkonfirmasi, angka kesembuhan mencapai 798.810, sementara itu angka kematian telah mencapai 27.835 orang meninggal dunia.

\footnotetext{
11 Savitri, F. M. (2021). Optimalisasi Strategi Polri Dengan Adanya Aplikasi EMutasi Dalam Pelaksanaan Tugas Bhabinkamtibmas Guna Mendukung Penerapan Protokol Kesehatan Selama Pandemi Covid-19 Di Polda Jateng. Jurnal Litbang Polri, Edisi Januari 2021, hlm. 71-81.

${ }^{12}$.https: / / nasional.kompas.com/read/2021/01/23/15232411/update-bertambah12191-kini-ada-977474-kasus-covid-19-di-indonesia?page=all. diakses pada 23/01/2021.
} 


\section{Tabel 1}

Data perkembangan Covid-19 di Indonesia $\left.{ }^{*}\right)$

\begin{tabular}{|l|l|}
\hline Dirawat & 162.617 \\
\hline Terkonfirmasi & $989.262+11.788$ \\
\hline Sembuh & 798.810 \\
\hline Meninggal & 27.835 \\
\hline
\end{tabular}

*) Data diolah bersumber dari www.covid19.go.id last update: 24-012021 15:50 WIB.

Secara khusus untuk Provinsi Nusa Tenggara Barat, ada 2.669 orang pasien yang dirawat, 6.940 orang terkonfirmasi Positif, 4.004 orang dinyatakan sembuh, dengan 267 orang meninggal. Peraturan atau kebijakan yang telah ditetapkan oleh pemerintah tentu sangat berpengaruh terhadap segala sektor, termasuk perekonomian dan kehidupan sosial dalam masyarakat. Berdasarkan informasi di media ini beberapa hari lalu bahwa lebih kurang 50 juta orang terancam kehilangan pekerjaan akibat dampak dari pandemi Covid-19, sulit untuk dibayangkan bila terjadi pengangguran, maka masalah sosial akan terus bermunculan. Selain itu, dampak dari pengaruh pandemi Covid19 dalam kehidupan sosial masyarakat, diantaranya adalah timbulnya rasa curiga dan hilangnya kepercayaan terhadap orang-orang yang ada di seputaran kita atau yang baru kita kenal. Dengan berpengaruhnya Covid-19 terhadap perekonomian yang terjadi, maka dikhawatirkan kondisi tersebut berimbas pada masalah sosial lainnya, di antaranya adalah semakin meningaktnya tingkat kejahatan yang terjadi dalam masyarakat. ${ }^{13}$

Dalam konteks tersebut, Presiden Joko Widodo (Jokowi) telah mengeluarkan Instruksi Presiden (Inpres) Nomor 6 Tahun 2020 tentang Peningkatan Disiplin Dan Penegakan Hukum Protokol Kesehatan Dalam Pencegahan Dan Pengendalian Corona Virus Diseae 2019. Ini merupakan langkah untuk memastikan protokol kesehatan diterapkan secara disiplin dan patuh oleh semua pihak. Kepala Biro Penerangan Masyarakat Divisi Humas Kepolisian Republik Indonesia (Polri) Awi Setiyono menyampaikan

\footnotetext{
${ }^{13}$.Budhi Suria Wardhana, Kompleksitas Tugas Kepolisian pada Masa Pandemi Covid-19. Jurnal Ilmu Kepolisian | Volume 14 | Nomor 2 | Agustus 2020, hlm. 8088.
} 
hal tersebut di Media Center Satuan Tugas Penanganan Covid19. ${ }^{14}$

Dalam Intruksi Presiden ini poin Kedua angka 5, Presiden secara khusus menginstruksikan Kepala Kepolisian Negara Republik Indonesia untuk:

a. memberikan dukungan kepada gubernur, bupati/wali kota dengan mengerahkan kekuatan Kepolisian Negara Republik Indonesia untuk melakukan pengawasan pelaksanaan protokol kesehatan di masyarakat;

b. bersama Panglima Tentara Nasional Indonesia dan instansi lain secara terpadu dengan pemerintah daerah menggiatkan patroli penerapan protokol kesehatan di masyarakat;

c. melakukan pembinaan masyarakat untuk berpartisipasi dalam upaya pencegahan dan pengendalian Corona Virus Disease 2019 (COVID-19); dan

d. mengefektifkan upaya penegakan hukum terhadap pelanggaran protokol kesehatan.

Awi menyampaikan bahwa dalam Inpres tersebut memuat empat poin yang diarahkan khusus kepada Polri:

a. Pertama, Presiden Jokowi memerintahkan Polri untuk turut mendukung dengan mengawasi penerapan protokol kesehatan;

b. Kedua, Polri diminta bersinergi dengan Tentara Nasional Indonesia (TNI) dan Pemerintah Daerah (Pemda) dalam melakukan patroli;

c. ketiga, Polri diarahkan untuk melakukan pembinaan kepada masyarakat dengan tujuan supaya masyarakat ikut berpartisipasi dalam mencegah penyebaran Covid-19 di Indonesia;

d. keempat, efektivitas penegakkan hukum terkait pelanggaran protokol kesehatan.

Pemberdayaan masyarakat dengan membuat program Kampung Tangguh di berbagai daerah. Dalam program Kampung Tangguh, masyarakat diminta memindai, menganalisis, serta mengambil tindakan pemecahan masalah yang sedang terjadi. Langkah $3 \mathrm{M}$ merupakan protokol kesehatan yang disosialisasikan

${ }^{14}$.https://covid19.go.id/p/berita/peran-polri-dan-tni-implementasikan-instruksipresiden-nomor-6-tahun-2020 diakses pada 25/01/2021 
oleh pemerintah, sebagai penyingkatan dari memakai masker, menjaga jarak dan mencuci tangan. Mengenai penegakkan hukum yang sifatnya denda, Awi mengatakan bahwa hal tersebut adalah pilihan terakhir. Penegakkan hukum pun dilakukan sesuai dengan peraturan daerah yang dibuat oleh pemda masing-masing. Selagi masih dapat dilakukan pembinaan dalam upaya mengajak masyarakat untuk menerapkan protokol kesehatan, Polri akan mengedepankan hal tersebut. Lebih lanjut, Awi mengajak masyarakat untuk disiplin diri dalam mematuhi protokol kesehatan dan tidak menganggap pandemi Covid-19 ini sebagai konspirasi belaka.

Sejak awal terjadinya Pandemi Covid 19, Polri berperan sangat aktif dalam membantu Pemerintah mengatasi pandemi Covid-19. Pada masa transisi menuju kehidupan Normal Baru, Polri juga sangat sigap melaksanakan perintah Presiden untuk mengawal. Polri melaksanakan upaya-upaya sebagai berikut:

a Pertama, preventif: menerbitkan Surat Telegram Rahasia untuk panduan anggota melaksanakan Tindakan-tindakan pada masa pandemi dan masa transisi Normal Baru, Binmas, Sabhara, Lalu Lintas dan satker-satker lainnya terlibat aktif memberikan informasi dan penyadaran pada masyarakat. Bersama-sama dengan Pemerintah Daerah menjaga keamanan dan ketertiban masyarakat dengan memanfaatkan teknologi, misalnya dengan CCTV, drone, aplikasi-aplikasi online. Merangkul masyarakat dengan humanis, sehingga masyarakat yang terdampak Covid-19 secara kesehatan maupun secara ekonomi dapat survive.

b Kedua: preemtif: melakukan patrol-patroli dan razia-razia untuk mencegah kejahatan.

c Ketiga: penegakan hukum sebagai upaya terakhir bagi orangorang yang melakukan perlawanan meski melanggar, termasuk memerintahkan pengendara motor dan mobil untuk putar balik karena larangan mudik Lebaran. ${ }^{15}$

Tak kurang, Polri mengeluarkan maklumat, Mak/2/III/2020, sebagai langkah memidana orang yang berkumpul, di Cafe atau sejumlah tempat nongkrong lainnya. Rationya ialah untuk menekan laju penularan virus Covid-19.

\footnotetext{
15 . https://kompolnas.go.id/tugas-polri-semakin-berat-di-masa-pandemi/ diakses pada $23 / 01 / 2021$
} 
Tentu Polri berharap masyarakat takut lalu patuh, karena selama ini kebijakan macam begini diyakini efektif. Maklumat Polri ini bisa didekati dengan paradigma institusionalisme, di mana suatu institusi yang mengeluarkan kebijakan tertentu memprioritaskan cara-cara yang menjadi ciri utama dari institusi tersebut. Tentu saja institutional branding dari institusi tersebut turut diselipkan ketika merancang kebijakan tertentu dimaksud.

Polri yang memang tengah memainkan peran besar dalam politik penegakan hukum hari-hari ini, hendak "menunjukkan" kerja-kerasnya mendukung program Pemerintah menanggulangi virus Covid-19. Bukan tanpa ekses, institutional branding, layaknya virus, dapat bermutasi menjadi bentuknya yang kontraproduktif, menggeser Indonesia dari Negara hukum (rechtstaat) menjadi Negara Polisi (politiestaat). Fenomena ini, dicocokkan dengan Covid-19, boleh jadi dinamakan "politiestaat$19^{\prime \prime}$ yang untuk banyak sendi perikehidupan masyarakat akan direspons dengan ancaman pidana sehingga nantinya polisi yang akan memainkan peran amat penting dalam penataan keteraturan di dalam negara politiestaat-19 ini. $^{16}$

Namun faktanya di lapangan, banyak masyarakat yang tidak mengikuti protokol kesehatan sesuai anjuran pemerintah, hampir seluruh masyarakat tidak mengikuti protokol kesehatan yang disampaikan oleh pemerintah dan ini disebabkan beberapa hal sebagai berikut:

a Disebabkan faktor kebutuhan, masyarakat memilih bekerja di luar rumah dibanding tetap tinggal dirumah;

b Sulit mendapatkan masker;

c Adanya kebiasaan tidak betah tinggal di rumah;

d Adanya persepsi bahwa virus corona belum menyebar di wilayah tempat tinggalnya.

Ketika masyarakat tidak mengikuti anjuran pemerintah yang disebabkan oleh beberapa hal diatas, berarti mereka tidak melakukan gerakan pencegahan penyebaran virus Covid-19. Bila gerakan pencegahan tidak dilakukan artinya ini akan mempercepat proses penyebaran virus, dan protokol kesehatan yang disampaikan oleh pemerintah pun tidak akan efektif sebab

\footnotetext{
${ }^{16}$ Ariehta Eleison Sembiring. Virus Corona dan Politiestaat-19. TRIFIDA at Law, diakses dari laman https://www.researchgate.net/publication/340298389 November 2021.
} 
masyarakat tidak mengimplementasikannya dalam kehidupan sehari-hari. ${ }^{17}$

\section{PENUTUP}

Polri telah melaksanakan tugas guna mendukung penerapan protokol kesehatan selama pandemi Covid-19 dalam rangka terwujudya situasi kamtibmas yang kondusif. Hal tersebut dilaksanakan dengn cara antara lain: Pertama, preventif: menerbitkan STR untuk panduan anggota melaksanakan Tindakantindakan pada masa pandemi dan masa transisi Normal Baru, Binmas, Sabhara, Lalu Lintas dan satker-satker lainnya terlibat aktif memberikan informasi dan penyadaran pada masyarakat. Bersamasama dengan Pemerintah Daerah menjaga keamanan dan ketertiban masyarakat dengan memanfaatkan teknologi, misalnya dengan CCTV, drone, aplikasi-aplikasi online. Merangkul masyarakat dengan humanis, sehingga masyarakat yang terdampak Covid-19 secara kesehatan maupun secara ekonomi dapat survive. Kedua: preemtif: melakukan patrol-patroli dan razia-razia untuk mencegah kejahatan. Ketiga: penegakan hukum sebagai upaya terakhir bagi orang-orang yang melakukan perlawanan meski melanggar, termasuk memerintahkan pengendara motor dan mobil untuk putar balik karena larangan mudik Lebaran. Atas segala kinerja Polri di Masa Pandemi Covid-19, hasil survei salah satu lembaga survey menyatakan masyarakat puas dengan kinerja Polri di tengah pandemi virus corona (Covid-19).

\footnotetext{
${ }^{17}$.Walsyukurniat Zendrato, Gerakan Mencegah Daripada Mengobati Terhadap Pandemi Covid-19, Jurnal Education and development Institut Pendidikan Tapanuli Selatan, Vol.8 No.2 Edisi Mei 2020, hlm. 242-248
} 


\section{DAFTAR PUSTAKA}

Buku \& Jurnal

Alam, K., \& Kusumah, A. D. (2021). Optimalisasi Strategi Polmas Guna Mendukung Penerapan Protokol Kesehatan Selama Pandemi Covid-19 Dalam Rangka Terwujudnya Situasi Kamtibmas Yang Kondusif. Yustitia, 7(1), 40-56.

Aulia Fitri. TNI-Polri Dan Program Vaksinasi Nasional. Kajian Singkat Terhadap Isu Aktual Dan Strategis. Vol. XIII, No.4/II/Puslit/Februari/2021. Pusat Penelitian Badan Keahlian DPR RI, hlm. 25-30

Budhi Suria Wardhana, Kompleksitas Tugas Kepolisian pada Masa Pandemi Covid-19. Jurnal Ilmu Kepolisian | Volume 14 |

Nomor 2 | Agustus 2020, hlm. 80-88

Hermawan Sulistyo, et.al., Keamanan Negara, Keamanan Nasional, dan Civil Society: Policy Paper, Pensil-324, Jakarta, 2009

Ibrahim, Johnny. "Teori dan metodologi penelitian hukum normatif." Malang: Bayumedia Publishing, (2006). hlm 295

Irwansyah, Penelitian Hukum Pilihan Metode \& Praktik Penulisan Artikel, Yogyakarta, Mirra Buana Media, (2021), Hlm 133. 152

Marzuki, Mahmud. Penelitian Hukum: Edisi Revisi. Prenada Media, 2017. hlm 137

Savitri, F. M. (2021). Optimalisasi Strategi Polri Dengan Adanya Aplikasi E-Mutasi Dalam Pelaksanaan Tugas Bhabinkamtibmas Guna Mendukung Penerapan Protokol Kesehatan Selama Pandemi Covid-19 Di Polda Jateng. Jurnal Litbang Polri, Edisi Januari 2021, hlm. 71-81

Telaumbanua, D. (2020). Urgensi Pembentukan Aturan Terkait Pencegahan Covid-19 di Indonesia. QALAMUNA: Jurnal

Pendidikan, Sosial, Dan Agama, 12(01), 59-70. 1.290

Walsyukurniat Zendrato, Gerakan Mencegah Daripada Mengobati

Terhadap Pandemi Covid-19, Jurnal Education and development Institut Pendidikan Tapanuli Selatan, Vol.8 No.2 Edisi Mei 2020, hlm. 242-248

Website

Ariehta Eleison Sembiring. Virus Corona dan Politiestaat-19. TRIFIDA at Law, diakses dari laman 
https://www.researchgate.net/publication/340298389 November 2021.

http: //www.padk.kemkes.go.id/article/read/2020/04/23/21/hinda ri-lansia-dari-covid-19.html diakses pada 23/01/2021

https: / / kompolnas.go.id/tugas-polri-semakin-berat-di-masapandemi / diakses pada 23/01/2021

http: / /infopublik.id/kategori/lawan-covid-19/453015/upaya-polridalam-menghadapi-pandemi-covid-19 diakses pada 27/01/2021

https://nasional.kompas.com/read/2021/01/23/15232411/updatebertambah-12191-kini-ada-977474-kasus-covid-19-diindonesia?page=all. diakses pada 23/01/2021.

https://covid19.go.id/p/berita/peran-polri-dan-tniimplementasikan-instruksi-presiden-nomor-6-tahun-2020 diakses pada 25/01/2021

https://kompolnas.go.id/tugas-polri-semakin-berat-di-masapandemi/ diakses pada 23/01/2021 